\title{
Highlights in Managing Monetary Policy of Vietnam in Post-Crisis Period
}

\author{
Truong Cong Bac (Corresponding author) \\ Faculty of Commerce, Van Lang University \\ 69/68 Dang Thuy Tram Street, Binh Thanh District, Ho Chi Minh City, Vietnam \\ Tel: 0944777367 E-mail: congbac92@gmail.com
}

Phan Quan Viet

Faculty of Commerce, Van Lang University

69/68 Dang Thuy Tram Street, Binh Thanh District, Ho Chi Minh City, Vietnam

E-mail: phanquanviet@vanlanguni.edu.vn

Vu Thi Kim Hanh

Faculty of Commerce, Van Lang University

69/68 Dang Thuy Tram Street, Binh Thanh District, Ho Chi Minh City, Vietnam

E-mail: vuthikimhanh@vanlanguni.edu.vn

Ho Thi Phuong Thao

Faculty of Commerce, Van Lang University

69/68 Dang Thuy Tram Street, Binh Thanh District, Ho Chi Minh City, Vietnam

E-mail: hothiphuongthao@vanlanguni.edu.vn

\section{Le Huong Duong}

Faculty of Commerce, Van Lang University

69/68 Dang Thuy Tram Street, Binh Thanh District, Ho Chi Minh City, Vietnam

E-mail: vuthikimhanh@vanlanguni.edu.vn 


\author{
Nguyen Ho Viet Anh \\ Faculty of Commerce, Van Lang University \\ 69/68 Dang Thuy Tram Street, Binh Thanh District, Ho Chi Minh City, Vietnam \\ E-mail: nguyenhovietanh@vanlanguni.edu.vn
}

\author{
Received: December 31, 2019 Accepted: January 17, 2020 Published: February 9, 2020 \\ doi:10.5296/jad.v6i1.16162 URL: https://doi.org/10.5296/jad.v6i1.16162
}

\begin{abstract}
This paper focuses on assessing highlights in the managing monetary policy in post-crisis period from 2011 to present in Vietnam in order to identifies key messages which helped Vietnam overcome the financial crisis 2007-2008 and keep the growth rate stably at high level, to be one of highest growth rate in the world. The research used aggregated methods, descriptive statistics and analysis based on World Bank, International Monetary Fund, Central Bank of Vietnam data sources. The results shown that the monetary policy in Vietnam in this period had a flexible transition in its management objectives, coordinated in close with fiscal policy to achieve macro goals, besides changing the regulatory mechanism by volume to operating with interest rates and combined with other operating tools more diverse.
\end{abstract}

Keywords: Monetary policy, post-crisis period, developing countries, Vietnam

\title{
1. Introduction
}

The financial crisis 2007-2008 affected the advanced economies of the United States and Western Europe initially then spilled over developing countries with unexpectedly powerful and caused the worst recession the world has witnessed for over six decades. It has involved almost countries and is stronger in intensity and coverage than of earlier crises which contained Great Depression in 1930's and Asian Financial Crisis in 1997 (Dhameja, 2010). After the crisis, the world economic situation recovering was slower than prediction, the public debt crisis took place seriously in many countries. In order to cope with this complex happening, countries did use different policies to limit the damage caused by the crisis and promote economic development however the actions in the management of financial crisis were different from countries to countries and the results therefore were various. Some countries that were less affected, avoided recession, and recovered sooner than expected while other countries have gotten difficult to find a way to return the growth trajectory until present.

With the trend of globalization, Vietnam's economy is increasingly integrating both depth and breadth in the world economy. Therefore, economic and monetary activities were becoming more and more fluctuated when the global economy context was complicated movement. Vietnam was among the countries which were not affected directly by the crisis but still 


\section{MInstitute ${ }^{\text {Mink }}$}

affected when the demand in partner countries were decreased lowly During the first time of post-crisis period from 2011 up to now, the world and domestic economic situation was complicated, domestic economy revealed many instable macroeconomic, high inflation, economic grew slowly down. Specially the countries were affected by the banking crisis, leading to the trend of decreasing investment and lack of capital. In order to overcome the difficult situation, the Central Bank of Vietnam has vigorously renovated the management of monetary policy in an active manner, leading the market contributing to adjust the monetary policy in efficiency, basically having the proposed objectives, contributing to get macroeconomic stable, promoting economic development and achieving a record growth at $7.02 \%$ in 2018. Wherefore, scientifically identifying new points in conducting monetary policy is a task of researchers and policy makers in Vietnam. To accomplish this, the author conducts research on the tools used to manage the monetary policy of the Central Bank in the period from 2011. The remainder of the paper is organized as follows: Section 2 will discuss literature which provide a background for understanding the monetary policy and relevant empirical research in responses for financial crisis. In the section 3, research methods and data will be introduced. Analysis results will be presented in section 4 . The final section will discuss the findings, conclude the paper

\section{Literature review}

There have been many researchers in the world have come up with different concepts about monetary policy, however in generally researchers define monetary policy based on the decisions and measures of monetary regulators to influence to the amount of money supply and the interest rate is aimed at achieving certain goals. According to Shaw (1977), monetary policy was as a willed action of monetary regulators to change the amount and availability or cost of "interest" money. The same opinion, Johnson (1965) said that monetary policy is the policy of the Central Bank to control money supply as a tool to achieve the goals of common economic policy. Kent (1966) defined monetary policy was the management of expanding or tightening the amount of money in circulation for clear purposes to achieve special goals such as without unemployment. Rowan (1983) argued that monetary policy is defined as an arbitrary action which taken by the operator to design the impact on money supply and money costs. Besides the definitions were given by researchers, the central banks in countries have also built their own views on monetary policy. Typically, the US Federal Reserve (FED) defined monetary policy is as actions affecting the availability and cost of money and credit to achieve the goals which selected by Congress. Meanwhile, the European Central Bank got idea monetary policy is as actions that executed by the Central Bank by using policy tools to achieve policy goals in which particularly price stability. In Vietnam, with accordance of Decree No. 82/2007/ND-CP stipulated providing information for the building and administrating the national monetary policy, in Article 2, "National monetary policy is a part of The State's economic and financial policies with aim having stability of money's value, curbing inflation, taking a part in promoting to socio-economic development, ensuring national defense and security and improving people's lives. In 2010, the Central Bank of Vietnam Law was enacted, in Article 3 of the Central Bank Law 2010 stipulated "National monetary policy is monetary decisions at the national level by competent state authorities, 


\section{MInstitute ${ }^{\text {Mink }}$}

consisting of determining the target of the money value stability expressed by the inflation spending, the decision to use the tools and methods to execute the planed goals". It can be said that, although the expression of researchers and central banks in different countries, nevertheless almost recognized that monetary policy is the process which the central bank uses tools to regulate the money supply to have monetary values stable, participating in the implementation of the government's macro-economic goals.

Base on situation of each country, the actions in managing monetary policy will be given and there will no commonly correct policies for every country (Jonung, 2008). However, from past experiences and analysis of financial crises, the developing countries would need to have combined actions across the time: immediate, short-term and long-term. In each stage, the objectives are different. As for actions in "immediate", the objective just be containment of financial panic. In next period, short-term policy responses are required to minimize the impact on the real economy and restore the confidence in financial systems. After that, in long-term, countries need to focus on strengthening and developing financial systems (Naudé, 2009). Developing countries should consider expansionary monetary policy because of the combination of crisis and liquidity trap. In this case, expansionary policy will become ineffective however there is solution for this is to strengthen the balance sheets of banks and consumers (Heinemann, 2008). In developing countries, the weak institutional framework will reduce drastically the role of securities markets and increases the cost of bank lending to private firms or a low level of financial development will result in the dominance of the bank-lending channel (Mishra, Montiel, and Spilimbergo, 2010). Additionally, the absence of evidence for strong monetary transmission in developing countries will be interpreted by economic conditions and methodological deficiencies (Mishra and Montiel, 2013).

As for researches about monetary policy, there are very sparse published studies about Vietnam and it is more limited empirical studies. Goujon (2006) showed that management of exchange rate fluctuations combined with a restrictive monetary policy based on broadly defined money helped to succeed in fighting inflation in Vietnam. Phuc and Duc-Tho (2009) analyzed consistency of exchange rate policy with a number of possible key policy objectives in Vietnam by compiling for both the nominal and real effective exchange rates (NEER and REER). Hung and Pfau (2009) investigated monetary transmission mechanism by using the vector auto-regression approach (VAR) and they found the consistent evidence that monetary policy can affect real output while the connection between money and inflation is less clear. With the same approach, Vo and Nguyen (2017) analyzed the impact of monetary policy through three channels (interest rate, exchange-rate and asset price) by employing a VAR model. Anwar and Nguyen (2018) also investigated monetary transmission mechanism with VAR models however they complemented the foreign shocks besides interest rate and exchange rate. Nguyen et al. (2019) studied about assessing the effects of monetary policy on the Vietnamese economy which was very close and important to our paper was research by performing a vector auto-regressive analysis. This study concentrated attention on price and output effects of monetary policy in Vietnam. The results showed that through the manipulation of interest rates, monetary policy would become and effective tool in stabilizing prices while credit growth tends to induce inflationary pressures. 


\section{Macrothink}

Journal of Asian Development

ISSN 2377-9594 2020, Vol. 6, No. 1

\section{Research Method and Data}

This study used descriptive statistics combined with analysis methods. In detail, the authors base on vector auto-regressive (VAR) analysis results about monetary policy in Vietnam from research of Nguyen et al. (2019) and other aggregated secondary data, the paper will describe the situation the change in monetary policy operating through charts, tables of comparative data according to time trends. From that, the paper will assess the effects of monetary policy and simultaneously figure out the highlights in managing monetary policy of Vietnam in post-crisis period.

Data sources are mainly taken from reports of the World Bank, International Monetary Fund. Besides that, the paper also used the empirical research results about monetary policy about Vietnam which is published of other scholars. These data are used to comparing the situation of Vietnam. In additionally, the data from General Statistics Office, Central Bank of Vietnam are also used to analysis the changing in Monetary policy in post-crisis period.

\section{Research Results}

\subsection{Change in Monetary Policy Targets}

Entering in the period of 2011-2013, the domestic economy has to face many difficulties such as high inflation, stagnant production and business, many enterprises were stopped operating, dissolved, went bankrupt, purchasing power of the market was declined, the real estate market was frozen, bad debt was increased ... Remarkably, there were times, the lending interest rate level was "escalated" to 22-24\%/year, VND was depreciated, foreign reserves was limited, public investment efficiency was low, deficit was high, solvency the banking system was weak, some commercial banks were put at risk. Facing these difficulties, the Government issued Resolution 11/NQ-CP on February 24, 2011, which identified the central task of the Central Bank in operating monetary policy is to "implementing cautious - tight monetary policy" in order to achieve the goals: To curb inflation, stabilizing the macro-economy, accomplishing solutions to remove difficulties for production and business activities to support reasonable economic growth, ensuring the safety of the credit system".


Figure 1. Impulse responses of industrial production and prices to shocks in Interest rate policy 


\section{Macrothink}

Note: Reprinted from "Assessing the price and output effects of monetary policy in Vietnam: evidence from a VAR analysis," by Thi Mai Lan Nguyen, Elissaios Papyrakis \& Peter A.G Van Bergeijk, 2019, Applied Economics, 51:44, 4800-4819. 2019 by "the Authors".

From Figure 1 we can see that the impulse response functions of output and price levels to a shock (measured by a one standard deviation increase) in policy interest rate with $95 \%$ confidence intervals (Nguyen et al. 2019). In the period from 2014 to the present, when our country's socio-economic situation had many positive changes, in the right direction and achieved the said overall goal. Macroeconomic was stable, lower inflation, the growth was higher than the previous year; The major balances of the economy were improved. In this situational context, the Government issued Resolution 01/NQ-CP on January 2, 2014 and expressed through Directive 01/CT-NHNN dated January 15, 2014, which defines the duties in operating monetary policy as: "Performing flexible and effective monetary policies" to achieve the goals: Control inflation, stabilizing macro-economy, and support reasonable economic growth. Operating reasonable rates, interest rates. Carrying out measures to expand credit associated with control, enhanced credit quality (Table 1).

Table 1. Goal and reality of inflation and GDP growth (From 2011 to present)

\begin{tabular}{|c|l|l|l|l|l|l|l|l|l|}
\hline \multicolumn{2}{|c|}{ Index (\%/Year) } & $\mathbf{2 0 1 1}$ & $\mathbf{2 0 1 2}$ & $\mathbf{2 0 1 3}$ & $\mathbf{2 0 1 4}$ & $\mathbf{2 0 1 5}$ & $\mathbf{2 0 1 6}$ & $\mathbf{2 0 1 7}$ & $\mathbf{2 0 1 8}$ \\
\hline \multirow{2}{*}{} & Goal & 6 & $6.5-7$ & 5.5 & 6 & 6.2 & 6.7 & 6.7 & 6.7 \\
\cline { 2 - 10 } & Reality & 5.89 & 5.03 & 5.42 & 5.98 & 6.68 & 6.21 & 6.81 & 7.08 \\
\hline \multirow{2}{*}{} & Goal & 18 & $<7$ & 8 & 7 & $5-7$ & $<5 \%$ & 4 & 4 \\
\cline { 2 - 10 } & Reality & 18.13 & 6.81 & 6.04 & 4.09 & 0.87 & 4.74 & 3.53 & 3.54 \\
\hline
\end{tabular}

Source: General Statistics Office

It can be seen that the final goal of monetary policy is always to control inflation, stabilize macro-economy, and support growth. Nonetheless, compared to the previous periods, the period from 2011 to present monetary policy was flexible in operating based on fluctuations of the world and domestic. The Figure 1 showed that in the post-crisis period, the inflation of Vietnam was very high comparing to other countries in Southeast Asia, however, this indicator was improved rapidly from the peak $18.31 \%$ in 2011 to $6.81 \%$ in 2012 and $0.87 \%$ in 2015 then stable around 4\%. 


\section{Macrothink}

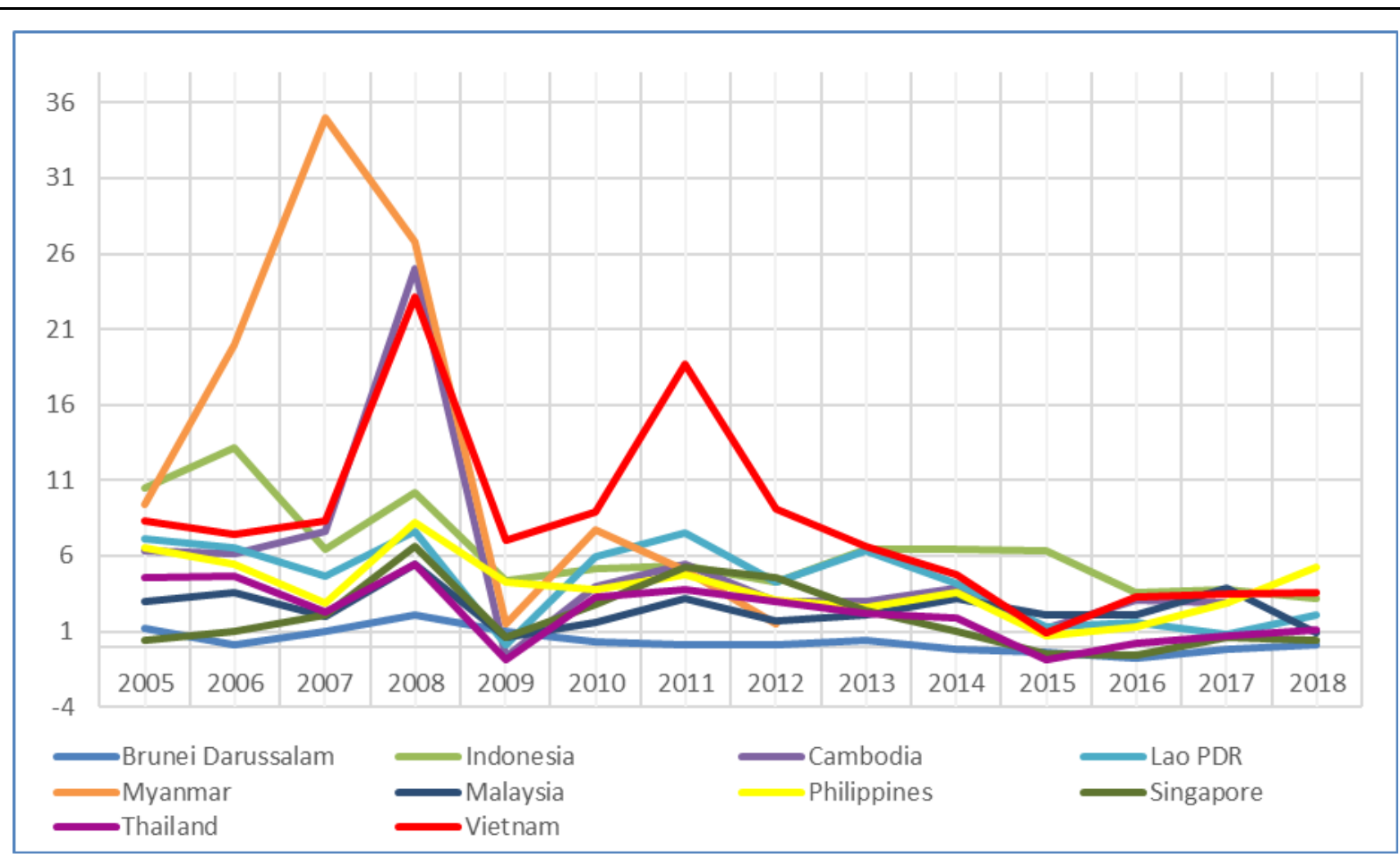

Figure 2. Inflation of Southeast Asia countries from 2005-2018

Source: International Monetary Fund

At the beginning, monetary policy focused on reducing losses, overcoming the effects of the post-crisis period by curbing inflation and macro stability. After that, when the economy became stable, the objective of monetary policy was not only the task of stabilizing the macro, curbing inflation, but also focused on supporting growth, controlling and enhancing credit quality. Regarding intermediate goals, the Central Bank changed from the mechanism of regulation by volume to controlling interest rates, tightly controlling the money supply, gradually focusing on the market interest rates target that suitable with inflation happening, money market was particular in solving difficulties for production and business activities. Along with efforts to reduce mobilization rates, the Central Bank of Vietnam did execute many methods to reduce lending interest rates, especially for priority areas, implementing a series of credit programs with preferential interest rates (Table 2). 
Table 2. Regulating maximum interest rate for short-term loans of the Central Bank

\begin{tabular}{|c|c|c|c|}
\hline Documents issued & $\begin{array}{l}\text { Date of } \\
\text { issuance }\end{array}$ & $\begin{array}{l}\text { Interest } \\
\text { rate }\end{array}$ & Subjects of Lending \\
\hline $\begin{array}{l}\text { Circular } \\
\text { 14/2012/TT-NHNN }\end{array}$ & $04 / 05 / 2012$ & $15 \%$ & $\begin{array}{l}\text { Agriculture, exporting goods, SMEs, } \\
\text { supporting industries }\end{array}$ \\
\hline $\begin{array}{l}\text { Circular } \\
\text { 33/2012/TT-NHNN }\end{array}$ & $21 / 12 / 2012$ & $12 \%$ & $\begin{array}{l}\text { Agriculture, exporting goods, SMEs, } \\
\text { supporting industries, high-tech }\end{array}$ \\
\hline $\begin{array}{l}\text { Circular } \\
\text { 10/2013/TT-NHNN }\end{array}$ & $10 / 05 / 2013$ & $10 \%$ & $\begin{array}{l}\text { Agriculture, exporting goods, SMEs, } \\
\text { supporting industries, high-tech }\end{array}$ \\
\hline $\begin{array}{l}\text { Circular } \\
\text { 16/2013/TT-NHNN }\end{array}$ & $27 / 06 / 2013$ & $9 \%$ & $\begin{array}{l}\text { Agriculture, exporting goods, SMEs, } \\
\text { supporting industries, high-tech }\end{array}$ \\
\hline $\begin{array}{l}\text { Decision } \\
\text { 499/QĐ-NHNN }\end{array}$ & $17 / 03 / 2014$ & $8 \%$ & $\begin{array}{l}\text { Agriculture, exporting goods, SMEs, } \\
\text { supporting industries, high-tech }\end{array}$ \\
\hline $\begin{array}{l}\text { Decision } \\
\text { 2713/QĐ-NHNN }\end{array}$ & $29 / 10 / 2014$ & $7 \%$ & $\begin{array}{l}\text { Agriculture, exporting goods, SMEs, } \\
\text { supporting industries, high-tech }\end{array}$ \\
\hline $\begin{array}{l}\text { Decision } \\
1425 / \mathrm{D}-\mathrm{NHNN}\end{array}$ & 07/07/2017 & $6.5 \%$ & $\begin{array}{l}\text { Agriculture, exporting goods, SMEs, } \\
\text { supporting industries, high-tech }\end{array}$ \\
\hline
\end{tabular}

Source: Central Bank of Vietnam

\subsection{Coordinating With Fiscal Policy}

Fiscal policy and monetary policy are the two most important policies in macroeconomic management, the combination of both policies will help overcome the limitations of each copper policy, at the same time to improve efficiency in achieving common goals. While monetary policy is related to the adjustment of money supply, fiscal policy is related to revenue and expenditure on the channels of the Ministry of Finance such as the State Treasury, Development Bank ... which are out of control the monetary of the Central Bank and these channels were important role in the monetary circulation of the country. In the previous stages, even though the coordination of these two policies was enhanced through resolutions and directives of the Government, the effectiveness, however the combination of these two policies was not really effective.

In the period of 2008 to 2011 , both monetary policy and monetary policy was applied 
maximum for macro stability requirements, restoring enterprise system, ensuring social security. Nevertheless, during the implementation, each policy often used its own tool and pursues its own policy goals. The fiscal policy must both comply with the requirements of controlling and cutting public spending, also executing the function of supporting enterprises and state corporations, meanwhile monetary policy must also curb inflation but at the same time had to maintain the stability of the banking system, sometimes these goals were conflict with the growth requirements or removing difficulties for the enterprise system. In addition, the lack of technical background, information sharing between policy agencies leaded to meet conflicts and difficulties in associating between policies. Forecast regarding to macroeconomic based on research on domestic and foreign influencing factors are important bases for setting goals, selecting policy tools and defining plan to perform policy implementation. Meanwhile, data platforms, information systems, forecasting techniques were not consistent, happening a difference in the forecast results of policy agencies. That was the reason, it was difficult for policy agencies to control the delay level in the effects of each policy, creating continuous changes, respond promptly to decisions and had to be repaired thereafter.

Nonetheless, from 2011 up to now, the coordination only shown a clear an effect when the Ministry of Finance and the Central Bank signed the Regulation on cooperation and information exchange, dated February 29, 2012, Decision No. 1317/QD-TTg approved the Scheme on coordination reform in macroeconomic management and administration on August 6, 2013. Together with building a legal lobby for macro-coordination mechanism, in fact, fiscal policy and monetary policy had step by step gradually coordinated smoothly; showing that if the previous period when there was a high risk of inflation, focusing on anti-inflationary measures by tightening fiscal policy - monetary policy, was made the growth rate decrease. After inflation was shown signs of being pushed back, policies to stimulate growth in the direction of easing fiscal - monetary, stimulating investment, stimulating consumption which were applied thoroughly, causing inflation to boom again, and this cycle was repeated many times, now the macro goals have been completed in a synchronized manner. It is clear that in the post-crisis period, almost growth rate of countries in Southeast Asia fluctuated significantly while this index of Vietnam is stable in high value around $6.5 \%$ (Figure 3). 


\section{MInstitute Macrothink $^{\text {Int }}$}



Figure 3. Growth rate of Southeast Asia countries from 2005-2018

Source: Word Bank

\subsection{Operating Monetary Policy Instruments}

\subsubsection{Refinancing, Rediscounting Combined With Open Market Operations}

Through open market operations and refinancing specialization, the Central Bank chose the operating target as the base amount to connect monetary policy instruments to intermediate targets. Considering the whole period from 2011 up to now, the interest rates of rediscounting and refinancing were flexibly used, these rates were only changed when there was a big fluctuation of the market and when the economy showed signs of stability, these interest rates were focused keep stable. In early 2011, the Central Bank increased the interest rate of refinancing from $9-12-13-14 \%$ and the interest rate of rediscounting increased from $7-12-13 \%$ in order to control inflation, stabilize the prime interest rate and continue increasing the interest rate of refinancing from $14 \%$ to $15 \%$ / year in October. Besides, the Central Bank has flexibly used the refinancing tool to support short-term capital for credit institutions to ensure stable liquidity for the system, and at the same time, supplement loan capital for effective production and business sectors. Since March 2012, in order to remove difficulties and create favorable conditions for production and business but still ensure inflation control and macroeconomic stability, the Central Bank has operated in a trend of reducing interest rates. In fact, due to inflation was gone down sharply and stably while difficulties in production and business activities, the Central Bank reduced interest rates of 


\section{MInstitute ${ }^{\text {Macrothink }}$}

refinancing from $15 \%$ to $9-7-6.5 \%$ / year, interest rates of rediscounting from $13 \%$ to $7-5-4.5 \%$ / year. In the period from 2014 to the present, with the stability of the economy, the interest rates of refinancing and rediscounting were kept stable: At $6.5 \%$ for interest rates of refinancing and $4.5 \%$ for interest rates of rediscounting. For open market operations, during the period of 2011-2013 when credit institutions continued to face difficulties in liquidity and borrowing in the inter-bank market, the Central Bank strengthened their support and injected VND into the market by offer to buy valuable papers, mainly for short terms of 7, 14, and 21 days on new year \& public holidays. Buying interest rates were adjusted down from $14 \%$ to 7-6.5-6-5.5-5\% in line with the Central Bank 's interest rates. When the macroeconomic situation became positive, the Central Bank adjusted the buying interest rate on the open market to encourage credit institutions to join the inter-bank market and enhance the role of the last lender of the Central Bank. In order to regulate the available capital of credit institutions and neutralize the money supply when buying into foreign currency reserves, the Stake bank promptly issued Stake bank bill of Credit with reasonable volumes and interest rates, terms were usually 28, 56, 84, 91, 154 and 182 days. Winning bid rates was also trended to decrease in line with market interest rates. From Figure 4, it is clear that the impulse response functions of output and price levels to a shock from Broad money policy (measured by a one standard deviation increase) with 95\% confidence intervals (Nguyen et al. 2019).
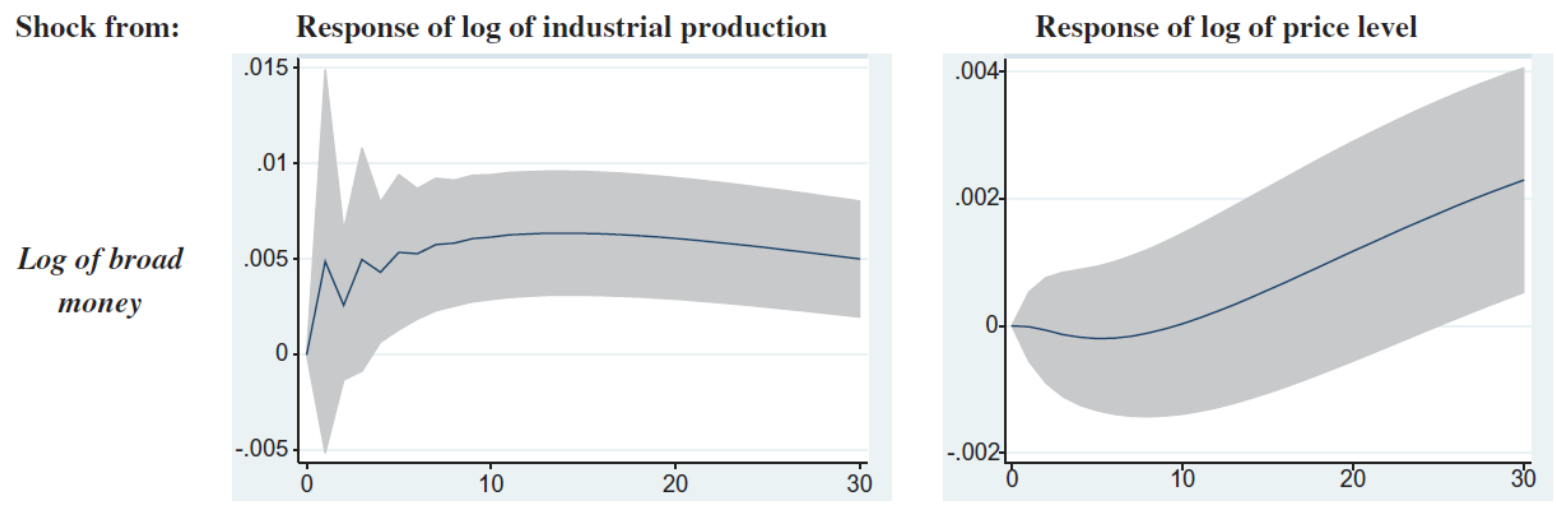

Figure 4. Impulse responses of industrial production and prices to shocks in Broad money policy

Note: Reprinted from "Assessing the price and output effects of monetary policy in Vietnam: evidence from a VAR analysis," by Thi Mai Lan Nguyen, Elissaios Papyrakis \& Peter A.G Van Bergeijk, 2019, Applied Economics, 51:44, 4800-4819. 2019 by "the Authors".

\subsubsection{Required Reserve Ratio Combined With Exchange Rate Management}

In the face of difficult economic conditions in 2011, with high inflation rate and the phenomenon of dollarization and goldlization, the Central Bank of Vietnam changed the exchange rate management mechanism in a proactive, flexible manner, taking measures 
buying and selling foreign currencies to intervene in the market when necessary. By regulating interbank rates in inter-bank market, combining exchange rate management with monetary policy to reduce pressure on exchange rates and foreign currency markets, maintaining the difference between VND and USD interest rates to ensure holding VND was more beneficial than USD, encouraging businesses and people to switch from holding USD to VND. In the period from 2011 up to now, the required reserve ratio for VND deposits has not been adjusted, while the average reserve ratio for foreign currency deposits has continuously changed before stabilizing. In 4 months from May 2011, the foreign currency deposit rate for foreign currencies increased from $4 \%$ to $6 \%-7 \%-8 \%$ for non-term deposits. For the terms and less than 12-month terms, from 2\% to $4 \%-5 \%-6 \%$ for over 12 month terms. This is an action to reduce the supply of foreign currency capital, limit credit growth in foreign currencies, overcome the situation of borrowing foreign currencies with low interest rates to convert them into VND for business capital. However, from September 2011 until now the required reserve rate for VND and foreign currencies has been keeping intact. Specifically, the required reserve ratio of Vietnam for VND was applied to commercial banks, branches of Central Banks, joint-venture banks, financial companies and financial leasing companies at $3 \%$ for non-term deposits and term deposits under 12 months, $1 \%$ for deposits with terms over 12 months. For foreign currency deposits, these rates were $8 \%$ and $6 \%$ respectively. On December 31, 2015, the Central Bank issued Decision No. 2730/QD-NHNN announcing the central exchange rate of VND against the US dollar, the cross rate of VND and some other foreign currencies. The Central Bank applied the new exchange rate mechanism as the central exchange rate, instead of the previous inter-bank average rate, the central rate was determined on the basis of reference to the average exchange rate movements in the inter-bank market, exchange rate movements in the international market of some currencies of countries with trade relationship, borrowing, debt repayment and big investment relations with Vietnam. Specifically, 8 currencies: USD, Thai Bath, EUR, CNY, Singapore dollar, Japanese yen, Korean won, and Taiwanese currency. The new method of managing the exchange rate allowed the exchange rate to flexibly fluctuate daily according to the movements of the supply and demand of foreign currencies in the country and fluctuate in the world market, while ensuring the management role of the Central Bank according to the regulations monetary policy direction. In additionally, Figure 5 showed that the shock in exchange rate policy led to responses of output and price levels (measured by a one standard deviation increase) with 95\% confidence intervals (Nguyen et al. 2019). 

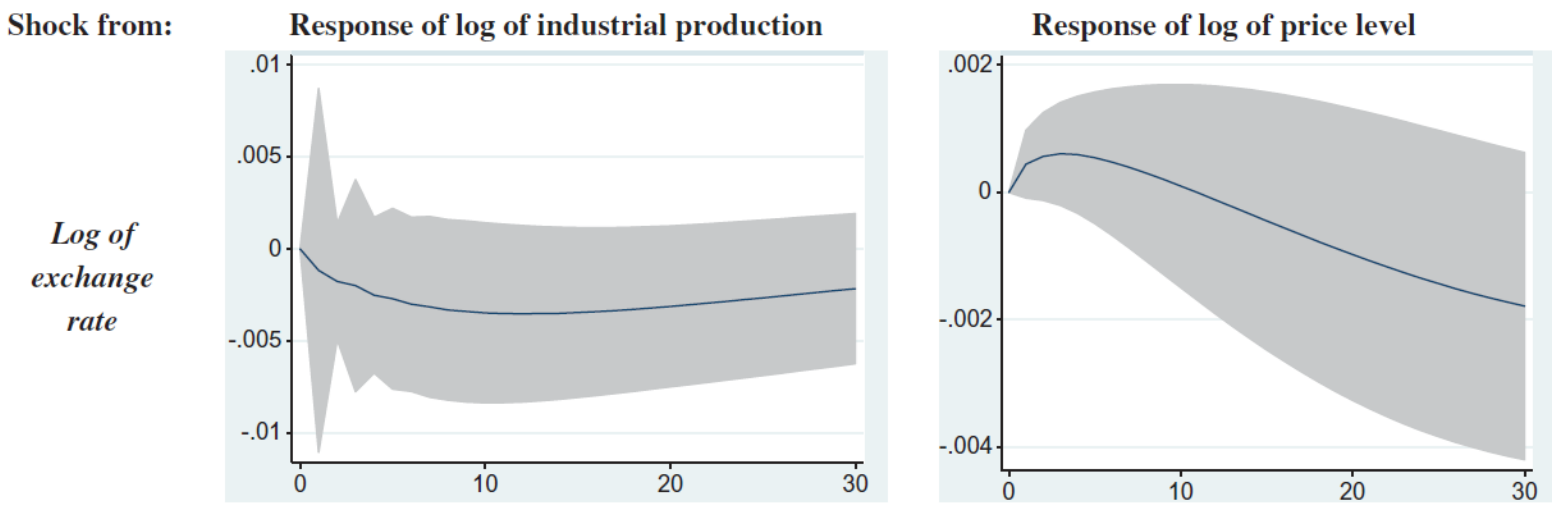

Figure 5. Impulse responses of industrial production and prices to shocks in Exchange rate policy

Note: Reprinted from "Assessing the price and output effects of monetary policy in Vietnam: evidence from a VAR analysis," by Thi Mai Lan Nguyen, Elissaios Papyrakis \& Peter A.G Van Bergeijk, 2019, Applied Economics, 51:44, 4800-4819. 2019 by "the Authors".

The announcement of the central exchange rate was a step taken by the Central Bank of Vietnam to accomplish the transparent goal of improving the position of the Vietnamese Dong, stabilizing the exchange rate and the foreign exchange market, and contributing to macroeconomic stability, supporting production and business activities of enterprises.

Table 3. Changes in exchange rates year by years (2011 - present)

\begin{tabular}{|l|l|l|l|l|l|l|l|l|}
\hline Year & $\mathbf{2 0 1 1}$ & $\mathbf{2 0 1 2}$ & $\begin{array}{l}\mathbf{0 6 / 2 0 1} \\
\mathbf{3}\end{array}$ & $\begin{array}{l}\mathbf{0 6 / 2 0 1} \\
\mathbf{4}\end{array}$ & $\mathbf{2 0 1 5}$ & $\mathbf{2 0 1 6}$ & $\mathbf{2 0 1 7}$ & $\mathbf{2 0 1 8}$ \\
\hline $\begin{array}{l}\text { Exchange } \\
\text { rate } \\
\text { (USD/VND) }\end{array}$ & 20.828 & 20.828 & 21.036 & 21.246 & 21.890 & $\approx 22.155$ & $\approx 22.735$ & $\approx 22,825$ \\
\hline $\begin{array}{l}\text { \% Change } \\
\text { Amplitude } \\
\text { (\%/year) }\end{array}$ & $\pm 2-3 \%$ & $\pm 2-3 \%$ & $\pm 2-3 \%$ & $\pm 1 \%$ & $\pm 1-3 \%$ & $\pm 1-3 \%$ & $\pm 2 \%$ & $\pm 2 \%$ \\
\hline
\end{tabular}

Source: Central Bank of Vietnam.

\subsection{Credit Control}

The Figure 6 depicted that the impulse response functions of output and price levels to a 


\section{MInstitute Macrothink $_{\text {Int }}$}

shock (measured by a one standard deviation increase) in credit policy with $95 \%$ confidence intervals (Nguyen et al. 2019). From that it can be seen that there was clear correlation between credit policy and output and price levels. In addition to monetary policy instruments, the Central Bank also controlled credit scale and quality. The Central Bank did request credit institutions to control credit growth, adjust structure and improve credit quality, focus credit capital for production and business, and reduce the rate and proportion of outstanding loans with non-manufacturing sector, solutions to remove difficulties for production and business activities following the policies of the Central Bank such as reducing lending interest rates and saving costs to facilitate credit expansion; review and assess the customers' solvency; rescheduling repayment term; restructure loans; consulting, creating favorable conditions for businesses with prospect of development, having products to meet market requirements but facing financial difficulties in obtaining bank loans to serve production and business; encourage lending to the model of linking production with the value added chain of products and applying high technology in agricultural production; Many credit policies were specific to industries, sectors and key products of the economy or related to people's lives.
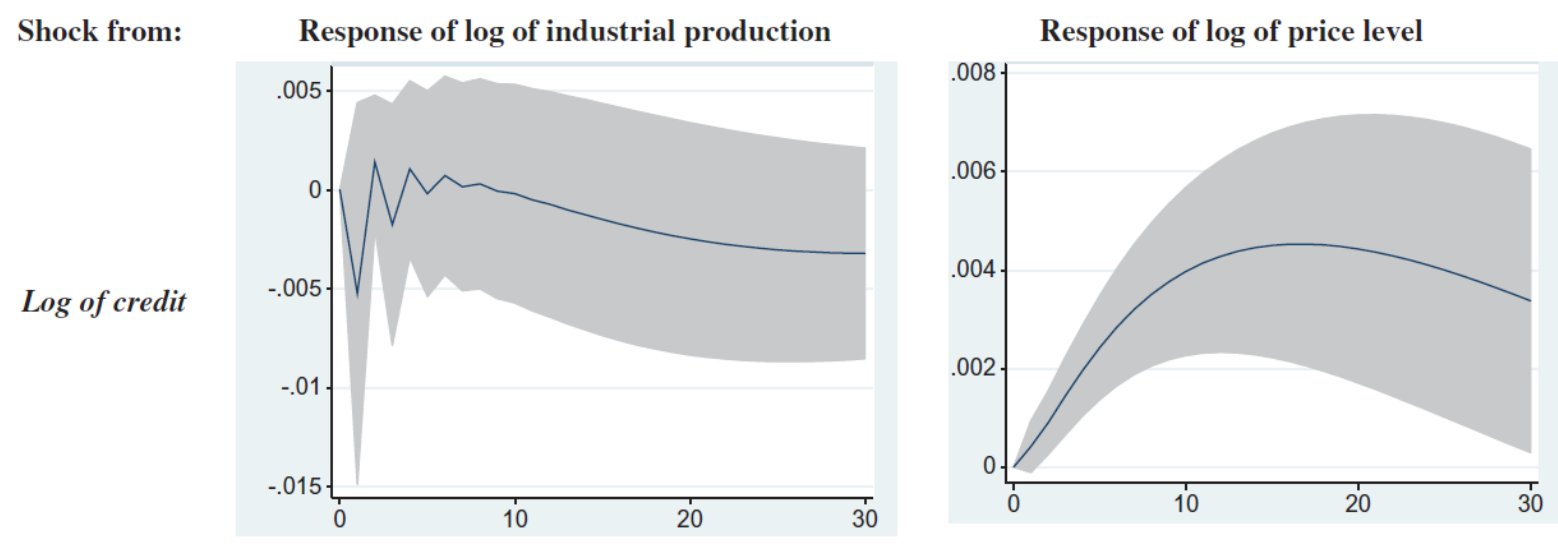

Figure 6. Impulse responses of industrial production and prices to shocks in Credit policy

Note: Reprinted from "Assessing the price and output effects of monetary policy in Vietnam: evidence from a VAR analysis," by Thi Mai Lan Nguyen, Elissaios Papyrakis \& Peter A.G Van Bergeijk, 2019, Applied Economics, 51:44, 4800-4819. 2019 by "the Authors".

\section{Discussion and Conclusion}

From the macroeconomic results from 2011 up to now, it can be seen that the process of operating monetary policy is relatively successful in the context of fluctuating world and domestic economy. This success is due to clear goals, flexible coordination between regulatory agencies, and the application of monetary policy in a synchronized manner. In the coming time, it is necessary to continue strengthening the coordination with the monetary policy in determining macro goals, which must comply with the overall coordination for that goal. In the short term, monetary policy and monetary policy need to work closely to achieve the goal of stabilizing the macro-economy, controlling inflation at a single digit and 
supporting growth, simultaneously removing difficulties for businesses, promoting promote production and business of enterprises. Monetary policy must be persistent with the goal of stabilizing inflation, the issue of controlling the price increase must be put to the forefront not only in periods of high inflation but even in times of low inflation in order to create confidence for market, build a stable macroeconomic environment. Continuing to use flexibly and coordinating monetary policy instruments to control money supply, operate based on interest rates, besides, it is necessary to set up a system of information provision, transparent implementation of expectations, policies as well as accountability of policy making and implementation agencies

\section{References}

Anwar, S., \& Nguyen, L. P. (2018). Channels of Monetary Policy Transmission in Vietnam. Journal of Policy Modeling, 40(3), 709-729. https://doi.org/10.1016/j.jpolmod.2018.02.004

Dhameja, N. (2010). Global financial Crisis: Impact, Challenges and Way Out. Indian Journal of Industrial Relations, 45(3), 336-349. https://www.jstor.org/stable/27768266

Goujon, M. (2006). Fighting Inflation in a Dollarized Economy: The Case of Vietnam. Journal of Comparative Economics, 34(3), 564-581. http://dx.doi.org/10.1016/j.jce.2006.06.001

Heinemann, F. (2008). Escaping from a Combination of Liquidity Trap and Credit Crunch. CESIfo Working Paper 2450. Munich: Ifo Institute for Economic Research

Hung, L. V., \& Pfau, W. D. (2009). VAR Analysis of the Monetary Transmission Mechanism in Vietnam. Applied Econometrics and International Development, 9(1), 165-179.

Johnson, H. G. (1965). Monetary Theory and Policy. In: Surveys of Economic Theory. Palgrave Macmillan, London. https://doi.org/10.1007/978-1-349-00278-8_1

Jonung, L. (2008). Lessons from Financial Liberalization in Scandinavia. Comparative Economic Studies, 50, 564-598. https://doi.org/10.1057/ces.2008.34

Kent, R. P. (1966). Money and Banking (5th ed). New York: Rinehart \& Winston.

Mishra, P., \& Montiel, P. (2013). How effective is monetary transmission in low-income countries? A survey of the empirical evidence. Economic Systems, 37(2), 187-216. https://doi.org/10.1016/j.ecosys.2012.12.001

Mishra, P., Montiel, P. J., \& Spilimbergo, A. (2010). Monetary transmission in low income countries. IMF Working Papers 10/ 223. Washington DC: International Monetary Fund. https://doi.org/10.5089/9781455208883.001

Naudé, W. (2009) The Financial Crisis of 2008 and the Developing Countries (Discussion Paper 2009/001. Helsinki: UNU-WIDER). Retrieved from https://www.wider.unu.edu/publication/financial-crisis-2008-and-developing-countries

Phuc, N., \& Duc-Tho, N. (2009). Exchange Rate Policy in Vietnam, 1985-2008. ASEAN Economic Bulletin, 26(2), 137-163. https://doi.org/10.1355/ae26-2a

Rowan, D. C. (1983). Macroeconomic Policy: Two Approaches. In: Output, Inflation and Growth. Palgrave Macmillan, London. https://doi.org/10.1007/978-1-349-06800-5_30

Shaw, G. K. (1977). An Introduction to the Theory of Macro-economic Policy (2nd ed.). 


\section{Macrothink}

Journal of Asian Development

ISSN 2377-9594 2020, Vol. 6, No. 1

London: Martin Robertson.

Thi Mai Lan, Nguyen, Elissaios, P. \& Van Bergeijk, P. A. G. (2019). Assessing the price and output effects of monetary policy in Vietnam: evidence from a VAR analysis. Applied Economics, 51(44), 4800-4819. https://doi.org/10.1080/00036846.2019.1602708

Vo, X. V., \& Nguyen, P. C. (2017). Monetary Policy Transmission in Vietnam: Evidence from a VAR Approach. Australian Economic Papers, 56(1), 27-38. https://doi.org/10.1111/1467-8454.12074

\section{Copyright Disclaimer}

Copyright for this article is retained by the author(s), with first publication rights granted to the journal.

This is an open-access article distributed under the terms and conditions of the Creative Commons Attribution license (http://creativecommons.org/licenses/by/4.0/). 